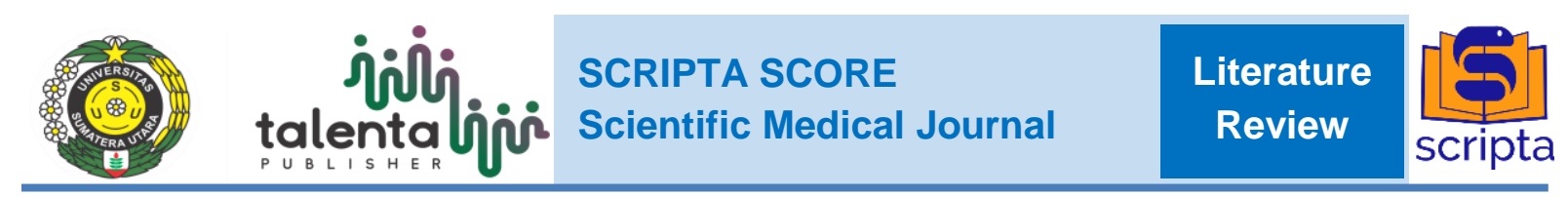

\title{
Endovascular Aortic Repair (EVAR) Method in the Management of Abdominal Aortic Aneursym
}

\author{
Abed Nego Okthara Sebayang ${ }^{1,2}$, Niko Azhari Hidayat ${ }^{3}$ \\ ${ }^{1}$ Department of Surgery, Faculty of Medicine, University of HKBP Nommensen, Medan \\ ${ }^{2}$ Vaskular Science Club \\ ${ }^{3}$ Vaskular Indonesia
}

\begin{abstract}
Aortic disease is a collection of diseases of the aorta, which includes aortic aneurysms; acute aortic infections consisting of aortic dissection, intramular hematoma, penetration of atherosclerotic ulcers (PAU) and traumatic injury to the aorta; pseudoaneurysm; aortic rupture; Marfan syndrome; and congenital abnormalities such as coarctation of the aorta. One of the aortic diseases that cause the death rate to increase according to the 2010 Global Burden Disease is aortic aneurysm. Abdominal aortic aneurysm (AAA) is a focal dilatation of the aortic segment. The diagnosis of AAA is done by history taking, physical examination and supporting examination. Management at AAA aims to prevent aortic wall rupture. An alternative procedure without open surgery is endovascular aortic repair (EVAR) using prostheses. It is expected that through the EVAR method, mortality and morbidity due to AAA can be reduced.
\end{abstract}

Keywords: abdominal aortic aneursym, EVAR, prostheses

\section{ABSTRAK}

Penyakit aorta merupakan kumpulan penyakit pada aorta yang meliputi aneurisma aorta; sindrom aorta akut berupa diseksi aorta, hematoma intramular, penetrating atherosclerosis ulcer (PAU) dan cedera akibat trauma pada aorta; pseudoaneurysm; ruptur aorta; sindrom Marfan; serta penyakit kongenital seperti koarktasio aorta. Salah satu penyakit aorta yang menyebabkan angka kematian meningkat menurut Global Burden Disease 2010 adalah aneurisma aorta. Aneurisma aorta abdominalis (AAA) merupakan dilatasi fokal pada segmen aorta. Penegakan diagnosis AAA dilakukan dengan anamnesis, pemeriksaan fisik dan pemeriksaan penunjang. Penatalaksanaan pada AAA bertujuan untuk mencegah pecahnya dinding aorta. Prosedur alternatif tanpa pembedahan terbuka yang dijadikan pilihan adalah endovascular aortic repair (EVAR) menggunakan protesa. Diharapkan melalui metode EVAR angka mortalitas dan morbiditas akibat AAA dapat diturunkan.

Kata kunci: aneurisma aorta abdominalis, EVAR, protesa

Received [17 Jan 2020] | Revised [26 Apr 2020] | Accepted [3 May 2020]

\section{INTRODUCTION}

Aortic disease is a collection of diseases of the aorta, which includes aortic aneurysms; acute aortic syndrome in the form of aortic dissection, intramular hematoma, penetrating atherosclerosis ulcer (PAU) and injury due to trauma to the aorta; pseudoaneurysm; and ruptured aortic syndrome. In the United States, aortic disease is the cause of 10,000 deaths each year. According to the 2010 Global Burden Disease project, the global death rate due to aortic aneurysm increased from 2.49 per 100,000 to 2.78 per 100,000 population between 1990 and 2010 with higher mortality in men. ${ }^{[1]}$

Aortic aneurysm is a vascular degenerative disease in the form of arterial dilatation, both localized and diffuse until it reaches a diameter of at least $50 \%$ greater than normal. There are two types 
of aortic aneurysm, namely abdominal aortic aneurysm (AAA) which is the most common case of aortic aneurysm with 95\% contribution. AAA occurs in the infrarenal segment. It is defined as AAA if the diameter of the aorta is greater than 3 $\mathrm{cm}$. The second type is a thoracic aortic aneurysm. The normal diameter of thoracic aorta is greater than the abdominal aorta; the diameter of the middescending thoracic aorta is $26-28 \mathrm{~mm}$ compared with the celiac axis which is only $20-23 \mathrm{~mm}$. It is said thoracic aortic aneurysm if the aortic size $>50 \%$ of normal size. ${ }^{[2]}$

The etiology of aortic aneurysm is believed to be a degenerative process due to genetic factors and the aging process. This degeneration process causes changes in collagen and elastin in the aortic wall, which causes weakness and dilation of the aortic wall. Based on their incidences, abdominal aortic aneurysms are more common than thoracic aortic aneurysms with a ratio of $1.7: 1 .^{[1,2]}$

The diagnosis of AAA is effectively and most frequently done by CT scan. The management of abdominal aortic aneurysms depends on the presence or absence of complications in the form of aortic rupture. Conventional management of AAA is open surgery through a laparotomy process. However, this method has disadvantages such as considerable bleeding, high infection rates and a long recovery period after surgery. An alternative currently developing treatment of AAA is a closed surgical procedure called an endovascular aortic repair (EVAR). ${ }^{[2]}$

\section{METHODS}

In this article, method used is the literature review. Literature study conducted by the author is by searching various written sources, whether in the form of books, archives, magazines, articles, and journals, or documents that are relevant to the problem being examined and listed in the bibliography. The information obtained from this literature study is used as a reference to strengthen the existing arguments. In this study, eleven sources were used consisting of various journals related to the management of an abdominal aortic aneurysm with the EVAR method. The analysis technique used is descriptive analysis of content analysis which is intended to describe in detail a message or a certain text.

\section{DISCUSSION}

Abdominal aortic aneurysm (AAA) is defined as distension of the infrarenal aortic wall more than $50 \%$ compared to normal size. Other sources state that although $90 \%$ of AAA cases are located in the infrarenal segment, about $10 \%$ remaining can involve the prarenal, visceral or even thoracoabdominal segments. ${ }^{[1,2]}$

There are several causes of aneurysm dilatation. A small number of AAA cases are a direct result of certain causes such as trauma, acute infections (brucellosis, salmonellosis), chronic infections (tuberculosis), inflammatory diseases (Behcet's disease, Takayasu) and connective tissue diseases such as Marfan syndrome, and Danlos type IV. However, most of the AAA are non-specific with several associated risk factors such as old age, smoking, male gender and family history of AAA. ${ }^{[2,3]}$

Nearly $30 \%$ of AAA cases are related to family history. This shows the tendency of predisposing factors to 'lowered' on AAA. AAA is one of the most diseases that are 'inherited'. The frequency is reduced in the first line relation around 15$19 \%$, compared to AAA sporadic which is only around $1-3 \% .^{[1,3]}$

Several studies have also shown an association between genetic disorders, such as gp21 chromosome abnormalities, and the onset of AAA. Other things that support the genetic factors association with 
AAA are: relatively younger age and higher tendency for rupture of familial AAA than those of sporadic AAA. The relative risk to families with familial AAA is 18 times higher than that of sporadic AAA. The ratio of sporadic AAA events between men and women is 5: 1, while familial AAA ratio is $2: 1 .^{[2,3]}$

The diagnosis of AAA is done by taking patient's history to look for risk factors that can be found in patients who are at high risk for the occurrence of AAA and then conduct a supplementary examination. The investigation used is ultrasound scanning, which is the first line method for AAA screening. This examination is a fast and safe examination and has nearly $100 \%$ sensitivity and specificity. Abdominal aortic diameter examination is carried out directly on the bedside using Vivid 6 portable echocardiography from General Electrics with a $2.5 \mathrm{MHz}$ cardiac probe. ${ }^{[3,4]}$

Management of AAA aims to prevent rupture of the aortic wall. If aneurysm rupture occurs, it will increase morbidity and mortality rates that are quite severe. Therefore, treatment at AAA must be based on the risk of action taken, the risk of aneurysm rupture, patient life expectancy, and patient preference. ${ }^{[1,4]}$

Before the 1990s, the management of AAA was carried out conventionally through open surgical procedures (Figure 1). Technically, the aneurysm is freed through a long laparotomy and frees the proximal portion distally to iliac with resection after systemic heparinisation (50$100 \mathrm{IU} / \mathrm{kgBB}$ ) and replaces it with a Dacron, Teflon or PTFE graft, either straight or Y-prosthesis. ${ }^{[2,4]}$ This open surgical procedure is quite difficult because it requires preparation in terms of heart physiology which must be free from coronary heart disease and examination of kidney physiology that is within normal limits. If abnormalities are found in the coronary artery stenosis, the surgical procedure is postponed until myocardial revascularization is performed first. ${ }^{[5,6]}$

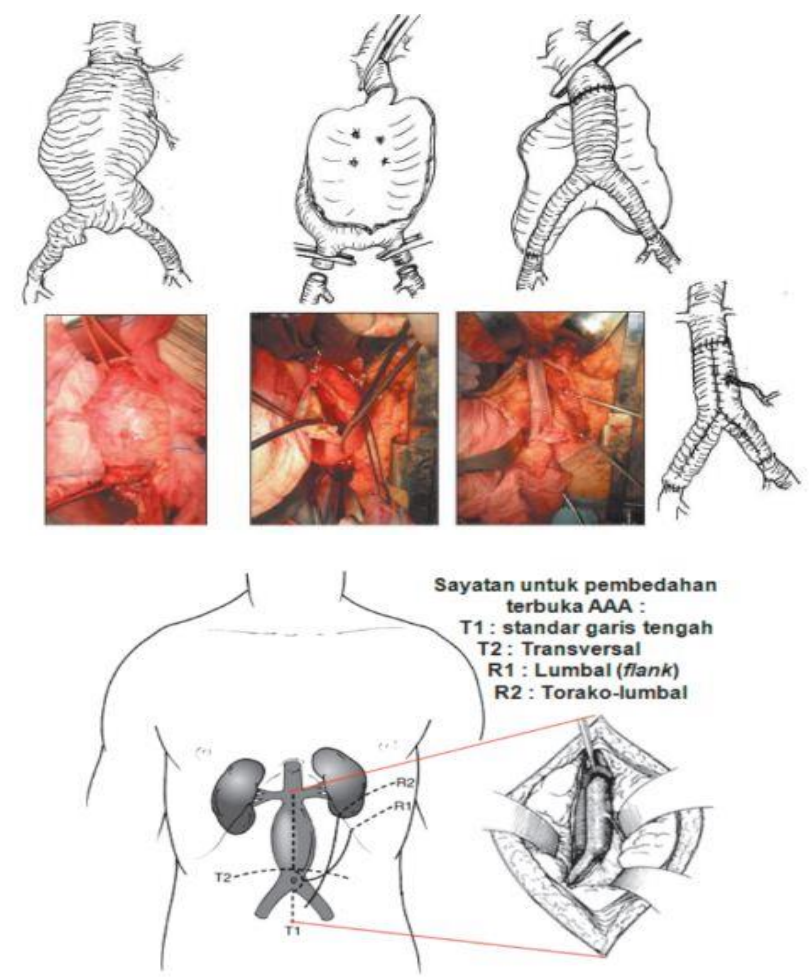

Figure 1. Incision method used at AAA open surgery ${ }^{[3]}$ 
This conventional method has several disadvantages such as having to be done by experienced surgeons, high heart failure and perioperative morbidity and high postoperative care. Open surgery in an emergency case has a high enough risk. For this reason, an indication of surgery for aortic aneurysm is when the patient has no symptoms (asymptomatic). ${ }^{[1,2,5]}$

An alternative management that can be considered in treating AAA is endovascular aortic repair (EVAR). This procedure is done in cardiac catheterization laboratory (cath lab) operating rooms or hybrid cath lab operating rooms without any resection and anastomosis, but it uses stent graft instead. ${ }^{[2,3,6]}$

In the EVAR method also applied a new vascular graft called "endograft". With endograft, surgical procedures can be performed with less bleeding. One of the difficulties in determining the indications for therapy by the EVAR method is the abnormal anatomic structure, morphology and aortic aneurysm structure that is very diverse in each patient. These can be analysed from careful observation of the radiological features (Figure 2). Observation and determination of the type of EVAR prosthesis that will be used will determine the success of AAA therapy, because generally the types of prosthesis offered are standard in width, length of leg $\mathrm{Y}$, hook type at the proximal edge where the prosthesis is anchored) are available. ${ }^{[4,5]}$ At present, the new fabrication technology offers for these parameters to be adjusted in advance with the anatomical, morphological features of the aortic aneurysm before action is taken and is referred to as a pre fabricated graft (pEVAR). In addition, there is also a socalled fenestrated graft (fEVAR), namely prosthesis/graft with fenestration allowing the catheter to enter the branches needed (renal, mesenterial, coeliac trunk) which can be used in aneurysm towards the proximal to the thoracic (Figure 3). ${ }^{[6,7]}$

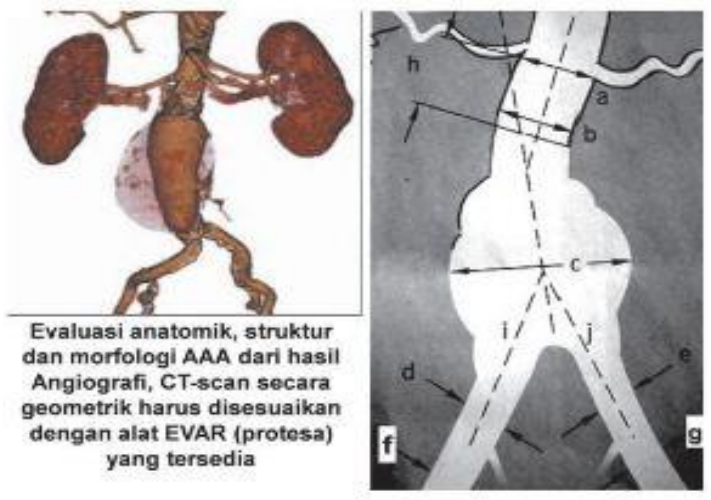

Figure 2. Preoperative determination of AAA diameter $^{[3]}$

The technical term that is commonly used is the EVAR endograft (eEVAR). Some of the results of research conducted in several multicenter using the prefabricated EVAR prosthesis application showed better results in handling AAA. What must be considered when using EVAR is the determination of interventional action strategies for anatomic abnormalities from the proximal neck of the aortic aneurysm to the branching of the iliac artery. ${ }^{[5,6,7]}$

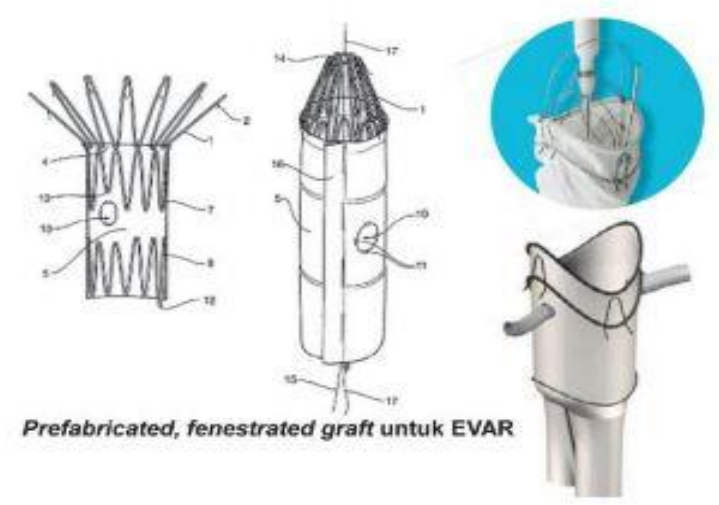

Figure 3. One example of fenestrated graft specially designed for use above the renal $\operatorname{arteries}^{[3]}$

The main and frequent complication of the EVAR procedure is the occurrence of "endoleak" post-treatment (Figure 4). Endoleak is a leak that occurs at the proximal base and the distal end of the prosthesis at the site of the landing zone of the prosthesis or the accompanying hook (replacing the suture where the anastomosis is in open surgery). ${ }^{[1,2,3]}$ Options for therapy in endoleaks are the 
installation of transcatheter coil, embolization with tissue glue, balloon angioplasty, endovascular graft placement and lastly open surgery. ${ }^{[6,8]}$
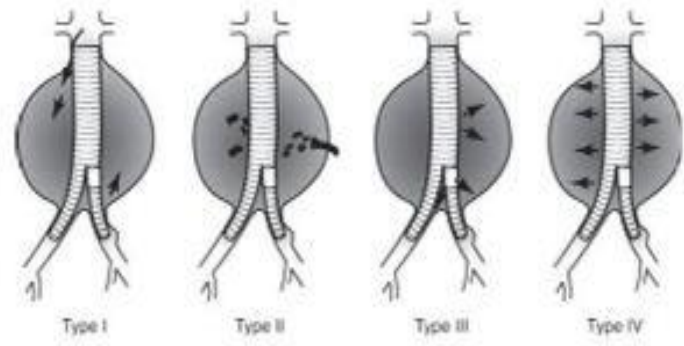

Figure 4. Endoleak is a complication that affects about $15-25 \%$ of patients who have $\operatorname{EVAR}^{[3]}$

\section{CONCLUSION}

Abdominal aortic aneurysm (AAA) is a vascular degenerative disease in the form of arterial dilatation, both localized and diffused until it reaches a diameter of at least $50 \%$ greater than normal. Management at AAA aims to prevent rupture of the aortic wall. An alternative procedure without open surgery is endovascular aortic repair (EVAR) using prostheses. It is expected that through the EVAR method, mortality and morbidity due to AAA can be reduced.

\section{REFERENCES}

[1] Tseng E, Bush ER. Thoracic aortic aneurysm [Internet]; 2018 Sep 05 [cited 2018]; Available from: https://emedicine.medscape.com/articl e/424904-overview

[2] Kuivaniemi $\mathrm{H}$, Platsoucas $\mathrm{CD}$, and Tilson MD 3rd. Aortic aneurysms: an immune disease with a strong genetic component.

Circulation. 2008;117(2):242-52. doi: 10.1161/CIRCULATIONAHA.107.69 $\underline{0982}$

[3] Rahimi SA. Abdominal aortic aneurysm; 2018 Nov 05 [cited 2018]; Available from: https://emedicine.medscape.com/articl e/1979501-overview\#a5
[4] Puruhito. Buku ajar primer: Ilmu bedah thorax, kardiak, dan vaskular. Surabaya: Airlangga University Press. Bandung; 2013. p. 373-80.

[5] Croenwett JL, Johnston KW. Rutherford's vascular surgery. $6^{\text {th }}$ ed. Philadelphia: Elsevier; 2005.

[6] Qu L, Raithel D. Experience with the Endologix Powerlink endograft in endovascular repair of abdominal aortic aneurysm with short and angulated necks. Perspect Vasc Surg Endovasc Ther. 2008;20(2):158-66. doi: $10.1177 / 1531003508320343$

[7] Fonseca R, Rockman C, Pitti A, Cayne N, Maldonado TS, Lamparello $\mathrm{PJ}$, et al. Intermediate-term EVAR outcomes in octogenarians. J Vasc Surg. 2010;52(3):556-60. doi: 10.1016/j.jvs.2010.03.051

[8] Jonathan DB, Gaines PA, editors. Vascular and endovascular surgery. $3^{\text {rd }}$ edition. Philadelphia: Elseiver; 2006 . 